\title{
Suitability of Irrigation and Drainage Waters in South El-Kalubia Governorate for Sustainable Agricultural Development under Salt Affected Soil Conditions
}

Heba S.A. Rashed

Soil Department, Faculty of Agriculture, Moshtohor, Benha University, Benha, Egypt.

\begin{abstract}
7 HE PURPOSE of this study was to assess water quality of irrigation and drainage waters in Southern part of El-Kalubia Governorate $\left(441.5 \mathrm{~km}^{2}\right)$. Stratified and random sampling was done to select representative water samples of irrigation and drain canals. Eleven water samples were taken from each of the irrigation canals and the drainage canals (drains). Eleven soil samples were also collected from the area. Water and soil samples were analyzed for $\mathrm{pH}$ and salinity. Out of the 11 irrigation water samples, 4 showed EC values below $0.75 \mathrm{dS} / \mathrm{m}$ being of " low to medium" salinity hazard, EC of the remaining was between 0.76 and $5.90 \mathrm{dS} / \mathrm{m}$ classified as of "high to very high" salinity hazard for irrigation. The $\mathrm{pH}$ was from 6.59 to 7.38 and SAR was from 1.46 to 7.98 in irrigation canals and classified as "low to high" for irrigation. Out of the 11 drainage water samples, 4 showed EC below $2.25 \mathrm{dS} / \mathrm{m}$ being of "low to medium" salinity hazard for irrigation. The remaining had EC of 2.42 to 7.46 $\mathrm{dS} / \mathrm{m}$ and classified as of "high to excessive" salinity for irrigation. The $\mathrm{pH}$ ranged from 7.04 to 7.85 and SAR was from 3.31 to 11.12 and classified as "medium to high" for irrigation. Drainage water in general could be suitable for irrigation by mixing with canal water. About $55 \%$ of the soils of the study area are saline non-sodic and $45 \%$ are non-saline non-sodic soils.
\end{abstract}

Keywords: Water quality, Irrigation water, Drainage water, Salinity hazard, Sodicity hazard, El-Kalubia Governorate.

Irrigated agriculture is dependent on adequate water supply of usable quality. In Egypt, water quality concerns have often been neglected because adequate supply of good quality water (Islam et al., 1999). High quality crops can be produced only by using high-quality irrigation water keeping other inputs optimal. Characteristics of irrigation water that define its quality vary with the source of the water. There are regional differences in water characteristics, based mainly on geology and climate (Rowe and Abdel-Magid , 1995). Poor-quality irrigation water becomes of more concern as the climate changes from humid to arid (Islam et al., 2009). Numerous parameters are used to define irrigation water quality and assess salinity hazards to determine appropriate management strategies (Tanji, 1990). Water quality analysis includes determination of total soluble salts and relative proportion some parameters. Among important 
parameters used for assessment of water quality are the followings: 1) salinity hazards, 2) sodium hazards, 3) carbonate hazards, 4) water $\mathrm{pH}$ and 5) specific ion hazards (Bauder et al., 2013).

In some areas water rainfall is available for crop growth, but many other areas require irrigation. For irrigation systems to be sustainable (Gold, 2009), they require proper management (to avoid salinization) and must not use more water from their source than is naturally replenished. Otherwise, the water source becomes a non-renewable resource several steps must be taken to develop drought-resistant farming systems even in "normal" years with average rainfalls. These measures include both policy and management actions to: 1) improve water conservation and storage measures, 2) provide incentives for selection of drought-tolerant crop species, 3) use reduced-volume irrigation systems, 4) manage crops to reduce water loss, or 5) stop planting crops. Sustainability affects overall production, which must increase to meet the increasing food and fiber needs as the world's human population expands to a projected 9.3 billion people by 2050 (Pasakarnis and Maliene, 2010). Sustainable agricultural development as a desired goal in irrigation management is a result of recent public awareness of the scarcity of water for food production. Irrigated crops play a vital role in securing global food production. Approximately $40 \%$ of world food is produced by irrigated crops, sustaining the livelihood of billions of people. In order to sustain irrigation, large amounts of water are withdrawn from rivers, lakes, reservoirs, and groundwater, together making up about $70 \%$ of global water withdrawals (Famiglietti, 2011).

Abraham et al. (2011) stated that irrigation increases food production in arid and semi-arid regions, and can enhance food security, promote economic growth and sustainable development, create employment opportunities, improve living conditions of. Sustainable development defined as 'development that meets the needs of the present without compromising the ability of future generations to meet their own needs'. Sustainable development of water resources involves considerations of population growth, urbanization, industrialization, land use practices, climate change and water recycling (McCarton and O'Hogain, 2013).

In the arid and semiarid climates, irrigation is often essential to achieve economically viable crop productions. Benefits from irrigation may be partially offset by detrimental effects of rising water tables and soil salinization, ineffcient water delivery systems and poor on-farm irrigation techniques (Kumar and Singh, 2003). Agricultural development strategies of most countries depend on the possibility of maintaining, improving and expanding irrigated agriculture (Siebert et al., 2006). However, as the pressure on water resources increases, irrigation is facing growing competition from other water-use sectors and could become a threat to the environment. Intensification of agricultural activities under arid or semiarid conditions involves irrigation, fertilization and application of other material to arable lands. In several developing countries irrigation represents up to $95 \%$ of all water withdrawals (Comprehensive Assessment of Water Management in Agriculture, 2007).

Egypt. J. Soil Sci. 54, No. 2 (2014) 


\section{Material and Methods}

\section{Location}

The area of study is located in southern part of El-Kalubia Governorate. ElKalubia is one of Lower Egypt governorates. It has a triangular shape with a base towards the south and top to the north. Geographically it lies between latitudes $31^{\circ} 5^{\prime}$ and $31^{\circ} 25^{\prime} \mathrm{N}$ and longitudes $30^{\circ} 10^{\prime}$ and $30^{\circ} 40^{\prime} \mathrm{E}$. and estimated to have an area of $441.5 \mathrm{~km}^{2}$. Fig. 1 shows the location of the studied area.

\section{Geomorphology of the area}

According to Zahra (2007) the main landforms (and their percent) in the area: flood plain (forms $96.4 \%$ of the area), hummocky area (forms $2.3 \%$ of the area), hilly lands (forms $1.2 \%$ of the area) and turtle back (forms $0.2 \%$ of the area).
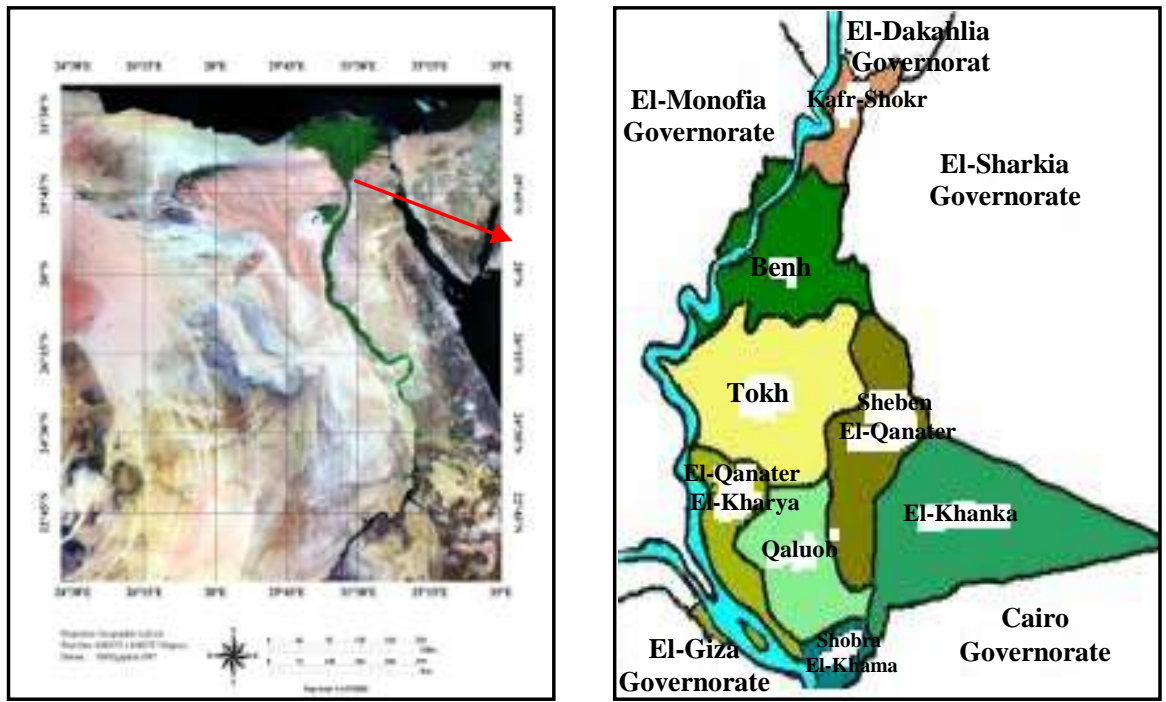

Fig. 1. Location map of the studied area.

Sampling sites of the surface waters, drainage waters and soil

Samples of soil and water irrigation were taken from 11 different irrigation canals and 11 different drains in the area (Table 1). 
TABLE 1. Locations and codes of water and soil samples.

\begin{tabular}{|c|c|c|c|c|c|}
\hline Location of Canals & $\begin{array}{c}\text { Canal } \\
\text { code }\end{array}$ & Location of drains & $\begin{array}{c}\text { Drain } \\
\text { Code }\end{array}$ & $\begin{array}{c}\text { Location of soil } \\
\text { sample }\end{array}$ & $\begin{array}{c}\text { Soil } \\
\text { sample } \\
\text { Code }\end{array}$ \\
\hline Qaluob canal & W1 & Qaluob drain & D1 & Qaluob & S1 \\
\hline Bahteem canal & W2 & Bahteem drain & D2 & Bahteem & S2 \\
\hline Senhera canal & W3 & Senhera drain & D3 & Senhera & S3 \\
\hline $\begin{array}{c}\text { Sheben El-Qanatter } \\
\text { canal }\end{array}$ & W4 & $\begin{array}{c}\text { Sheben El-Qanatter } \\
\text { drain }\end{array}$ & D4 & $\begin{array}{c}\text { Sheben El- } \\
\text { Qanatter }\end{array}$ & S4 \\
\hline Namoul canal & W5 & Namoul drain & D5 & Namoul & S5 \\
\hline Abo-Zaibl canal & W6 & Abo-Zaibl drain & D6 & Abo-Zaibl & S6 \\
\hline Tanan canal & W7 & Tanan drain & D7 & Tanan & S7 \\
\hline Mostorod canal & W8 & Mostorod drain & D8 & Mostorod & S8 \\
\hline $\begin{array}{c}\text { Aghour El-Sougra } \\
\text { canal }\end{array}$ & W9 & $\begin{array}{c}\text { Aghour El-Sougra } \\
\text { drain }\end{array}$ & D9 & $\begin{array}{c}\text { Aghour El- } \\
\text { Sougra }\end{array}$ & S9 \\
\hline Nawa canal & W10 & Nawa drain & D10 & Nawa & S10 \\
\hline Qaha canal & W11 & Qaha drain & D11 & Qaha & S11 \\
\hline
\end{tabular}

Soils

The soils in the study area vary from light sandy to heavy clay (Table 2). Substantial area of the cultivated land is dominantly covered by clay loam and clayey soils with a presence of fine sandy loam and sand soils in very limited areas.

TABLE 2. Area coverage of the different soil types.

\begin{tabular}{|l|c|}
\hline Soil type & Area coverage (fed) \\
\hline Clay & 58366 \\
\hline Clay loam & 27900 \\
\hline Sandy loam & 2023 \\
\hline Sand & 1223 \\
\hline
\end{tabular}

\section{Chemical analyses}

Soil and water samples were analyzed for salinity and soluble ions and $\mathrm{pH}$ according to methods cited by USDA (1954) and Rowell (1995).

Assessment of water for irrigation purposes

a) The USDA classification: Assessment in terms of salinity and sodicity hazards according to the USDA (1954) as modified by Thorn and Paterson (1955). Salinity was in 6 grades (classes) (in terms of EC values) starting from low salinity water $(<0.25 \mathrm{dS} / \mathrm{m})$ to moderate salinity water $(0.25-0.75 \mathrm{dS} / \mathrm{m})$, medium salinity water $(0.75-2.25 \mathrm{dS} / \mathrm{m})$, high salinity water $(2.25-4.00 \mathrm{dS} / \mathrm{m})$ and excessively high salinity water $(>6.00 \mathrm{dS} / \mathrm{m})$. Sodicity assessment was in 4 grades (classes) (in terms of SAR) of low sodicity water (<10 for low salinity water "lsw" down to $>2.8$ for high salinity water "hsw"); medium sodicity water (10 -18 for "lsw" down to 2.8 - 7 for "hsw"); high sodicity water (18 -26 for "lsw" down to $7-11$ for "hsw") and very high sodicity water (> 26 for "lsw" down to > 11 for "hsw"). Symbols for the salinity classes are C1, C2, C3, C4, C5 and C6 respectively, while those for the sodicity ones are S1, S2, S3 and S4, respectively. Fig. 2 shows the USDA classification.

Egypt. J. Soil Sci. 54, No. 2 (2014) 
SUITABILITY OF IRRIGATION AND DRAINAGE WATERS IN SOUTH... 153

b) The FAO classification: Assessment was done in 3 classes according FAO (1985) as shown in Table 3

TABLE 3. Guidelines for interpretation of water quality for irrigation FAO (1985).

\begin{tabular}{|c|c|c|c|c|c|}
\hline \multirow{2}{*}{\multicolumn{2}{|c|}{ Potential irrigation problem }} & \multirow{2}{*}{ Units } & \multicolumn{3}{|c|}{ Degree of restriction on use } \\
\hline & & & None & Slight to Moderate & Severe \\
\hline 1) Salinity hazards & $\mathrm{EC}_{\mathrm{w}}$ & $\mathrm{dS} / \mathrm{m}$ & $<0.7$ & $0.7-3.0$ & $>3.0$ \\
\hline \multirow{6}{*}{ 2) Infiltration hazards } & SAR $=$ & & & & \\
\hline & $0-3$ & & $>0.7$ & $0.7-0.2$ & $<0.2$ \\
\hline & $\begin{array}{l}3-6 \\
6-12\end{array}$ & & $>1.2$ & $1.2-0.3$ & $<0.3$ \\
\hline & $12-20$ & & $>1.9$ & $1.9-0.5$ & $<0.5$ \\
\hline & $20-40$ & & $>2.9$ & $2.9-1.3$ & $<1.3$ \\
\hline & & & $>5.0$ & $5.0-2.9$ & $<2.9$ \\
\hline
\end{tabular}

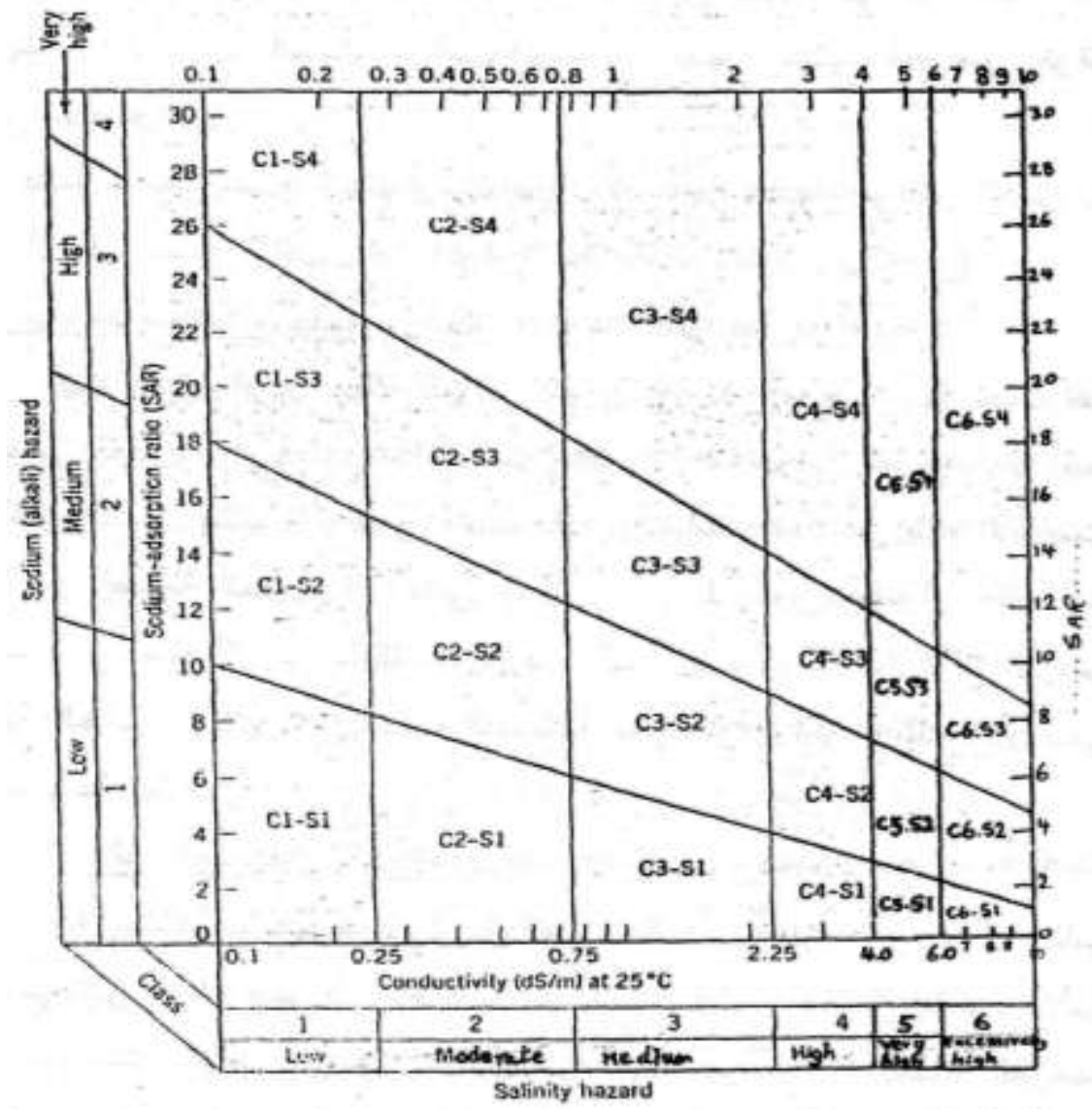

Classification of waters with regard to sodium and salinity hazards (USDA, 1954).

Egypt. J. Soil Sci. 54, No.2 (2014) 


\section{Results and Discussion}

Assessment of water for irrigation canals

The suitability of water depends on how it can be used as it is or under specific conditions. These conditions include tolerance of crops to salts (Burger and Čelková, 2001), physical and chemical properties of soil, management of irrigation methods, and climatic conditions. Criteria for assessment of water for irrigation must include all such factors. No universal scheme for the classification of irrigation water quality has been developed. Data on water samples are given in Table 4.

a) Assessment according to the USDA classification

Salinity assessment: Table 4 shows values of EC of the studied samples.Out of the eleven water samples, four have EC below $0.75 \mathrm{dS} / \mathrm{m}$ classified as "low to moderate salinity water". The remaining seven samples have EC ranging from 0.76 to $5.90 \mathrm{dS} / \mathrm{m}$ classified as "medium to very high salinity water". Thus, these are irrigation waters that are not hazardous and need no restriction on use and irrigation waters that need slight to very high degree of restriction on use.

TABLE 4. Properties of the canal waters under study.

\begin{tabular}{|c|c|c|c|c|c|c|c|c|c|c|c|}
\hline \multirow{2}{*}{$\begin{array}{c}\text { Surface } \\
\text { water } \\
\text { No. }\end{array}$} & \multirow{2}{*}{$\begin{array}{c}\text { Sample } \\
\text { Code }\end{array}$} & \multirow[t]{2}{*}{$\mathbf{p H}$} & \multirow{2}{*}{$\begin{array}{c}\mathrm{ECw} \\
(\mathrm{dS} / \mathrm{m})\end{array}$} & \multirow[t]{2}{*}{ SAR } & \multicolumn{4}{|c|}{ Cations $\left(\right.$ mmole $\left._{\mathrm{c}} / \mathrm{L}\right)$} & \multicolumn{3}{|c|}{ Anions $\left(\right.$ mmole $\left._{\mathrm{c}} / \mathrm{L}\right)$} \\
\hline & & & & & $\mathrm{Ca}^{2+}$ & $\mathrm{Mg}^{2+}$ & $\mathrm{Na}^{+}$ & $\mathbf{K}^{+}$ & $\mathrm{SO}_{4}{ }^{2-}$ & $\mathrm{Cl}^{-}$ & $\mathrm{HCO}_{3}$ \\
\hline \multicolumn{12}{|c|}{ Water of field canal } \\
\hline 1 & W1 & 7.26 & 0.44 & 1.87 & 1.35 & 1.27 & 2.14 & 0.31 & 1.52 & 1.76 & 1.79 \\
\hline 2 & W2 & 7.50 & 1.43 & 3.23 & 3.56 & 4.19 & 6.36 & 0.43 & 2.60 & 6.29 & 5.65 \\
\hline 3 & W3 & 7.75 & 0.70 & 2.77 & 1.78 & 1.54 & 3.57 & 0.29 & 1.57 & 2.78 & 2.83 \\
\hline 4 & W4 & 7.28 & 0.37 & 1.46 & 1.14 & 1.30 & 1.61 & 0.30 & 1.32 & 1.41 & 1.62 \\
\hline 5 & W5 & 7.39 & 1.42 & 2.95 & 4.11 & 4.52 & 6.13 & 0.44 & 6.75 & 4.61 & 3.94 \\
\hline 6 & W6 & 7.64 & 1.20 & 3.36 & 2.92 & 3.80 & 6.15 & 0.28 & 3.30 & 5.51 & 4.34 \\
\hline 7 & W7 & 7.52 & 5.90 & 7.98 & 14.66 & 12.72 & 29.54 & 1.23 & 15.68 & 34.82 & 7.65 \\
\hline 8 & W8 & 7.78 & 0.45 & 1.82 & 1.27 & 1.16 & 2.01 & 0.27 & 1.06 & 2.28 & 1.37 \\
\hline 9 & W9 & 7.31 & 1.48 & 3.89 & 3.51 & 4.40 & 7.74 & 0.36 & 5.65 & 6.33 & 3.53 \\
\hline 10 & W10 & 7.03 & 3.71 & 5.63 & 9.33 & 10.47 & 17.70 & 0.74 & 10.97 & 19.25 & 8.02 \\
\hline 11 & W11 & 7.38 & 0.76 & 3.32 & 1.90 & 2.12 & 4.71 & 0.37 & 2.16 & 2.34 & 3.25 \\
\hline
\end{tabular}

Note: $\left(\mathrm{CO}_{3}{ }^{2-}\right.$ values are below detection in all samples). SAR: Sodium. Adsorption Ratio.

The first type of irrigation water can be used for irrigation for almost all crops and for almost all kinds of soils. Slight salinity may develop in soil. However such water may raise problems in soils of extremely low permeability's. To achieve a full yield potential due to using the second type, gradually increasing care in selection of crop and management alternatives are required.

The W1, W3, W4, and W8 waters would be classified as C2-S1 (medium salinity, low sodicity) water while the W7 water is C5-S3 (very high salinity, high sodicity) water. The W10 water is C4-S3 (high salinity, high sodicity. The remaining $\mathrm{W} 2, \mathrm{~W} 5, \mathrm{~W} 6, \mathrm{~W} 9$ and $\mathrm{W} 11$ waters are C3-S2 (medium salinity, medium sodicity) water (Table 5).

Egypt. J. Soil Sci. 54, No. 2 (2014) 
TABLE 5. USDA Salinity, sodicity classification of the canal waters.

\begin{tabular}{|c|c|c|c|c|c|c|c|c|c|c|c|}
\hline \multirow[b]{2}{*}{$\begin{array}{l}\text { Water } \\
\text { type / }\end{array}$} & \multicolumn{6}{|c|}{ Salinity hazard* EC (dS/m) } & \multicolumn{4}{|c|}{ Sodicity hazard $^{* *}$ (SAR) } & \multirow{2}{*}{$\begin{array}{l}\text { Water } \\
\text { classifi } \\
\text { cation }\end{array}$} \\
\hline & $\begin{array}{c}\text { Class } 1 \\
\text { C1 }\end{array}$ & $\begin{array}{c}\text { Class 2 } \\
\text { C2 }\end{array}$ & $\begin{array}{c}\text { Class } 3 \\
\text { C3 }\end{array}$ & $\begin{array}{c}\text { Class } 4 \\
\text { C4 }\end{array}$ & $\begin{array}{c}\text { Class } 5 \\
\text { C5 }\end{array}$ & $\begin{array}{c}\text { Class } 6 \\
\text { C6 }\end{array}$ & $\begin{array}{c}\text { Class 1 } \\
\text { S1 }\end{array}$ & $\begin{array}{c}\text { Class } 2 \\
\text { S2 }\end{array}$ & $\begin{array}{c}\text { Class } 3 \\
\text { S3 }\end{array}$ & $\begin{array}{c}\text { Class } 4 \\
\text { S4 }\end{array}$ & \\
\hline W1 & & $*$ & & & & & $*$ & & & & C2-S1 \\
\hline W2 & & & * & & & & & $*$ & & & C3-S2 \\
\hline W3 & & $*$ & & & & & $*$ & & & & $\mathrm{C} 2-\mathrm{S} 1$ \\
\hline W4 & & $*$ & & & & & $*$ & & & & $\mathrm{C} 2-\mathrm{S} 1$ \\
\hline W5 & & & $*$ & & & & & $*$ & & & C3-S2 \\
\hline W6 & & & $*$ & & & & & * & & & $\mathrm{C} 3-\mathrm{S} 2$ \\
\hline W7 & & & & & * & & & & * & & C5-S3 \\
\hline W8 & & $*$ & & & & & $*$ & & & & $\mathrm{C} 2-\mathrm{S} 1$ \\
\hline W9 & & & $*$ & & & & & * & & & C3-S2 \\
\hline W10 & & & & * & & & & $*$ & & & C4-S2 \\
\hline W11 & & & $*$ & & & & & $*$ & & & $\mathrm{C} 3-\mathrm{S} 2$ \\
\hline
\end{tabular}

*: C1 to C6: low, moderate, medium, high, very high and excessive high, respectively.

**: S1 to S4: low, medium, high and very high, respectively.

Sodicity assessment: The SAR of water relative to its salinity has ramifications for both infiltration and the long-term stability of soil structure. In general, there is a risk of reduced infiltration and declining soil structure if the water has moderate to high SAR but low salinity. Using water with moderate to high salinity, regardless of whether SAR is high or low, means there is no reduction in the rate of infiltration, but the sodicity hazard still remains (Stephens, 2002). Out of the eleven samples, the W7 sample has SAR value of 7.98 and EC of $5.90 \mathrm{dS} / \mathrm{m}$. This indicates a need for very high degree of restriction on use. The SAR values of the reaming samples are ranging from 1.46 to 5.63 and can be put into two groups based on their EC. A group of SAR of up to 3 (W1, W3, W4, W5 and W8) and EC ranging from 0.37 to $0.70 \mathrm{dS} / \mathrm{m}$ except W5 sample whose EC is 1.42 . For them, these are no sodicity hazards.

$\mathrm{pH}$ assessment: The $\mathrm{pH}$ ranges between 7.03 and 7.78 indicating safe use for irrigation (Table 4).

\section{b) Assessment according to FAO classification}

Salinity assessment: The EC of canal water at studied area ranged from 0.37 to $5.90 \mathrm{dS} / \mathrm{m}$.

From the obtained data, it could be noticed that W1, W3, W4 and W8 waters are classified as "none" saline in the degree of restriction in use for irrigation. Salinity classes of W2, W5, W6, W9 and W11 waters have EC ranged from 0.76 to $1.48 \mathrm{dS} / \mathrm{m}$ are "slight to moderate" in the degree of restriction in use for irrigation and may cause salinity hazards in long run application. Salinity of W7 and W10 waters are classified as "severe" in the degree of restriction in use and may cause soil salinity problem in long run application. 
Sodicity assessment: The SAR of canal water at studied area ranged from 1.46 to 7.98 . The SAR values of $\mathrm{W} 2, \mathrm{~W} 5, \mathrm{~W} 7, \mathrm{~W} 9$ and $\mathrm{W} 10$ waters are classified as "none" in the degree of restriction in use for irrigation and salinity problems dose not exist. The waters of W1, W3, W4, W6, W8 and W11 are classified as "slight to moderate".

$\mathrm{pH}$ assessment: The $\mathrm{pH}$ values of all canals lies in normal range.

Suitability of drainage water for irrigation Purposes

Recharge of agricultural drainage water into the irrigation network is beneficial from the point of view of conserving water and increasing the efficiency of water use. According to Amer (1996) 7.2 billion cubic meters are used for irrigation purposes in Egypt and that drainage water is used to irrigate 1.97 million ha in the Delta of the total area of 3.11 million ha of Egyption total arable.

Chemical properties of the drainage water samples are given in Table 6.

TABLE 6. Properties of the drainage waters.

\begin{tabular}{|c|c|c|c|c|c|c|c|c|c|c|c|}
\hline \multirow{2}{*}{$\begin{array}{c}\text { Surface } \\
\text { water } \\
\text { No. }\end{array}$} & \multirow{2}{*}{$\begin{array}{c}\text { Sample } \\
\text { Code }\end{array}$} & \multirow[t]{2}{*}{ pH } & \multirow{2}{*}{$\begin{array}{c}\text { ECw } \\
(\mathrm{dS} / \mathrm{m})\end{array}$} & \multirow[t]{2}{*}{ SAR } & \multicolumn{4}{|c|}{ Cations (mmole $\mathrm{c} / \mathrm{L}$ ) } & \multicolumn{3}{|c|}{ Anions (mmole $\mathrm{c} / \mathrm{L}$ ) } \\
\hline & & & & & $\mathrm{Ca}^{2+}$ & $\mathrm{Mg}^{2+}$ & $\mathrm{Na}^{+}$ & $\mathbf{K}^{+}$ & $\mathrm{SO}_{4}{ }^{2-}$ & $\mathrm{Cl}^{-}$ & $\mathrm{HCO}_{3}{ }^{-}$ \\
\hline \multicolumn{12}{|c|}{ Drainage water } \\
\hline 12 & D1 & 7.16 & 2.15 & 5.10 & 4.72 & 5.71 & 11.58 & 0.30 & 6.32 & 11.63 & 4.36 \\
\hline 13 & $\mathrm{D} 2$ & 7.63 & 6.17 & 9.30 & 11.92 & 16.97 & 35.35 & 0.62 & 12.45 & 46.43 & 5.35 \\
\hline 14 & D3 & 7.21 & 1.44 & 3.31 & 4.21 & 3.65 & 6.56 & 0.31 & 4.77 & 6.44 & 3.52 \\
\hline 15 & D4 & 7.85 & 6.78 & 13.34 & 8.33 & 15.58 & 46.13 & 1.01 & 19.49 & 50.82 & 8.74 \\
\hline 16 & D5 & 7.63 & 7.46 & 11.12 & 13.98 & 24.86 & 48.85 & 1.14 & 33.26 & 47.34 & 7.53 \\
\hline 17 & D6 & 7.04 & 1.51 & 3.55 & 3.44 & 4.26 & 6.97 & 0.23 & 2.79 & 8.33 & 3.78 \\
\hline 18 & D7 & 7.68 & 5.32 & 10.61 & 9.48 & 11.32 & 34.17 & 0.52 & 8.11 & 41.47 & 5.91 \\
\hline 19 & D8 & 7.10 & 1.70 & 3.20 & 2.79 & 3.60 & 5.69 & 0.23 & 2.58 & 5.05 & 4.68 \\
\hline 20 & D9 & 7.74 & 2.42 & 8.95 & 4.77 & 2.89 & 17.52 & 0.19 & 8.75 & 11.87 & 4.77 \\
\hline 21 & D10 & 7.23 & 2.71 & 4.62 & 9.57 & 5.45 & 12.67 & 0.25 & 9.22 & 11.24 & 7.48 \\
\hline 22 & D11 & 7.46 & 3.97 & 9.12 & 7.43 & 9.32 & 26.38 & 0.64 & 15.22 & 21.61 & 6.95 \\
\hline
\end{tabular}

Note: $\left(\mathrm{CO}_{3}{ }^{2-}\right.$ values are below detection in all samples). SAR: Sodium Adsorption Ratio.

a) Assessment according to the USDA classification

Salinity assessment: Table 4 shows that out of the eleven water samples, four samples (D1, D3, D6 and D8) have EC below $2.25 \mathrm{dS} / \mathrm{m}$ and classified as "low to medium". These drainage waters can reuse directly or through mixing with fresh water without causing severe problems. The remaining seven samples (D2, D4, D5, D7, D9, D10 and D11) have EC ranging from 2.42 to $7.46 \mathrm{dS} / \mathrm{m}$ classified as "high to excessive high" and may cause salinity problem in long run application. 
The D4 and D5 waters would be classified as C6-S4 (excessive high salinity, very high sodicity) water while D9 and D11 waters are C4-S3 (high salinity, high sodicity) water. The D7 water is C5-S3 (very high salinity, high sodicity) water. The D2 water is C6-S3 (excessive high salinity, high sodicity) water. The D10 water is C4-S2 (high salinity, medium sodicity) water. The remaining D1, D3, D6 and D8 waters are C3-S2 (medium salinity, medium sodicity) water (Table 7).

Sodicity assessment: Out of the eleven samples, the D4 and D5 samples have SAR values above 11 and EC above 6. This indicates needs for very high degree of restriction on use. The SAR values of the remaining samples are ranging from 3.31 to 10.61 and $\mathrm{EC}$ ranging from 1.44 to $6.17 \mathrm{dS} / \mathrm{m}$.

$\mathrm{pH}$ assessment: The $\mathrm{pH}$ ranges between 7.04 and 7.85 indicating safe use for irrigation (Table 6).

TABLE 7. Salinity, sodicity hazards and drainage water classification.

\begin{tabular}{|c|c|c|c|c|c|c|c|c|c|c|c|}
\hline \multirow{2}{*}{$\begin{array}{l}\text { Water } \\
\text { type / }\end{array}$} & \multicolumn{6}{|c|}{ Salinity hazards ${ }^{*}$ EC (dS/m) } & \multicolumn{4}{|c|}{ Sodicity hazards ${ }^{* *}$ (SAR) } & \multirow{2}{*}{$\begin{array}{c}\text { Water } \\
\text { classifica } \\
\text { tion }\end{array}$} \\
\hline & $\begin{array}{c}\text { Class1 } \\
\text { C1 }\end{array}$ & $\begin{array}{c}\text { Class } 2 \\
\mathrm{C} 2\end{array}$ & $\begin{array}{c}\text { Class3 } \\
\text { C3 }\end{array}$ & $\begin{array}{c}\text { Class } 4 \\
\text { C4 }\end{array}$ & $\begin{array}{c}\text { Class5 } \\
\text { C5 }\end{array}$ & \begin{tabular}{|c|} 
Class6 \\
C6
\end{tabular} & $\begin{array}{c}\text { Class1 } \\
\text { S1 }\end{array}$ & $\begin{array}{c}\text { Class2 } \\
\text { S2 }\end{array}$ & \begin{tabular}{|c|} 
Class3 \\
$\mathrm{S3}$
\end{tabular} & $\begin{array}{c}\text { Class4 } \\
\text { S4 }\end{array}$ & \\
\hline D1 & & & $*$ & & & & & $*$ & & & $\mathrm{C} 3-\mathrm{S} 2$ \\
\hline D2 & & & & & & $*$ & & & $*$ & & C6-S3 \\
\hline D3 & & & $*$ & & & & & $*$ & & & $\mathrm{C} 3-\mathrm{S} 2$ \\
\hline D4 & & & & & & $*$ & & & & $*$ & C6-S4 \\
\hline D5 & & & & & & * & & & & * & C6-S4 \\
\hline D6 & & & $*$ & & & & & $*$ & & & $\mathrm{C} 3-\mathrm{S} 2$ \\
\hline D7 & & & & & $*$ & & & & $*$ & & $\mathrm{C} 5-\mathrm{S} 3$ \\
\hline D8 & & & $*$ & & & & & $*$ & & & $\mathrm{C} 3-\mathrm{S} 2$ \\
\hline D9 & & & & $*$ & & & & & $*$ & & $\mathrm{C} 4-\mathrm{S} 3$ \\
\hline D10 & & & & $*$ & & & & $*$ & & & $\mathrm{C} 4-\mathrm{S} 2$ \\
\hline D11 & & & & $*$ & & & & & $*$ & & $\mathrm{C} 4-\mathrm{S} 3$ \\
\hline
\end{tabular}

*: C1 to C6: low, moderate, medium, high, very high and excessive high respectively.

**: S1 to S4: low, medium, high and very high respectively.

b) According to FAO classification.

Salinity assessment: The EC ranged from 1.44 to $7.46 \mathrm{dS} / \mathrm{m}$. whereas SAR values.

From the obtained data, it could be noticed that D3 and D6 waters have low ECs below $1.56 \mathrm{dS} / \mathrm{m}$; they are 1.44 and $1.51 \mathrm{dS} / \mathrm{m}$, respectively. The EC of D1, D68, D9 and D10 waters from 1.70 to $2.71 \mathrm{dS} / \mathrm{m}$ are classified as "slight to moderate". It could be concluded that these waters could be reused directly of by mixing with canal water without causing severe problems. The EC of D2, D4, D5, D7 and D11 drains are ranged from 3.97 to $7.46 \mathrm{dS} / \mathrm{m}$. These waters are considered highly saline water and classified as "severe" in the degree of 
restriction in use and may cause soil salinity problem in long run application and hazards may occur due to soil permeability problem in long run application. This is mainly due to none official reusing of drainage water, which causes a corresponding, increase in drainage water salinity.

Sodicity assessment: The SAR of drain water ranged from 3.31 to 13.34 . The SAR values of all waters of the studied area are classified as "none" in the degree of restriction in use for irrigation and salinity problems dose not exist.

$\mathrm{pH}$ assessment: The $\mathrm{pH}$ values of all drains lies in normal range.

\section{Properties of soils of the area}

Properties of soils irrigated with the irrigation waters under study are given in the Table 8 are discussed below.

TABLE 8. Properties of the investigated soils.

\begin{tabular}{|c|c|c|c|c|c|c|c|c|c|c|c|}
\hline \multicolumn{2}{|c|}{ Sample } & \multirow{2}{*}{$\begin{array}{c}\mathrm{pH} \\
1: 2.5 \\
\text { Suspention } \\
\end{array}$} & \multirow{2}{*}{$\begin{array}{c}\mathrm{EC} \\
(\mathrm{dS} / \mathrm{m})\end{array}$} & \multicolumn{4}{|c|}{ Cations $\left(\mathbf{m m o l}_{\mathrm{c}} / \mathbf{L}\right)$} & \multicolumn{3}{|c|}{ Anions $\left(\mathbf{m m o l}_{\mathbf{c}} / \mathbf{L}\right)$} & \multirow[b]{2}{*}{ ESP } \\
\hline No. & Code & & & $\mathrm{Ca}^{2+}$ & $\mathrm{Mg}^{2+}$ & $\mathrm{Na}^{+}$ & $\mathbf{K}^{+}$ & $\mathrm{Cl}^{-}$ & $\mathrm{SO}_{4}^{2-}$ & $\mathrm{HCO}_{3}{ }^{-}$ & \\
\hline 23 & S1 & 7.48 & 1.70 & 5.58 & 4.94 & 6.83 & 0.42 & 5.87 & 7.36 & 4.64 & 3.03 \\
\hline 24 & S2 & 6.59 & 8.34 & 26.25 & 27.40 & 31.53 & 0.81 & 45.42 & 25.25 & 15.32 & 7.15 \\
\hline 25 & S3 & 6.74 & 1.66 & 4.59 & 5.27 & 6.64 & 0.33 & 6.47 & 4.23 & 6.11 & 3.07 \\
\hline 26 & S4 & 7.06 & 5.34 & 18.34 & 16.52 & 21.29 & 1.96 & 36.06 & 17.96 & 4.10 & 5.88 \\
\hline 27 & S5 & 6.65 & 11.14 & 42.73 & 34.12 & 46.16 & 1.71 & 48.22 & 40.84 & 35.63 & 8.85 \\
\hline 28 & S6 & 7.15 & 3.61 & 10.60 & 9.46 & 13.53 & 1.23 & 17.12 & 15.44 & 7.26 & 4.85 \\
\hline 29 & S7 & 7.46 & 5.34 & 16.43 & 17.62 & 21.57 & 0.95 & 35.65 & 14.04 & 6.88 & 6.05 \\
\hline 30 & S8 & 7.53 & 1.20 & 3.96 & 3.17 & 5.18 & 0.35 & 2.47 & 5.66 & 4.53 & 2.70 \\
\hline 31 & S9 & 7.13 & 4.88 & 15.47 & 13.29 & 18.73 & 1.24 & 25.49 & 11.65 & 12.59 & 5.97 \\
\hline 32 & $\mathrm{~S} 10$ & 6.85 & 2.10 & 6.66 & 5.15 & 9.97 & 0.62 & 11.67 & 4.71 & 6.02 & 4.56 \\
\hline 33 & S11 & 6.43 & 5.62 & 18.54 & 15.61 & 22.40 & 1.76 & 38.07 & 15.22 & 5.02 & 6.30 \\
\hline
\end{tabular}

Note: $\left(\mathrm{CO}_{3}{ }^{2-}\right.$ values are below detection in all samples). ESP: Exchangeable Sodium Percentage.

\section{Soil assessment}

Soil salinity and sodicity

The soil EC value ranged from $1.20 \mathrm{dS} / \mathrm{m}$ to $11.14 \mathrm{dS} / \mathrm{m}$ (Table 8 ). Soil of the highest salinity is a highly saline soil. Five soils out of the eleven soils are classified as saline, the other 6 soils are not saline (USDA, 1954). Exchangeable Sodium Percentage (ESP) ranged from 2.70 to 8.85 indicating no or slight sodicity (USDA, 1954). The $\mathrm{pH}$ of the soils ranges from 6.43 to 7.53 indicating no alkalinity.

Impact of EC, SAR of water (irrigation \& drainage) on EC, ESP of soil under studied samples

Figure 2 shows EC of irrigation water and EC of soil of the studied samples. Figure 3 shows of drainage water and EC of soil of the studied samples. Fig. 4

Egypt. J. Soil Sci. 54, No. 2 (2014) 
SUITABILITY OF IRRIGATION AND DRAINAGE WATERS IN SOUTH... 159

shows SAR of irrigation water and ESP of soil of the studied samples. Fig. 5 shows SAR of drainage water and ESP of soil of the studied samples.

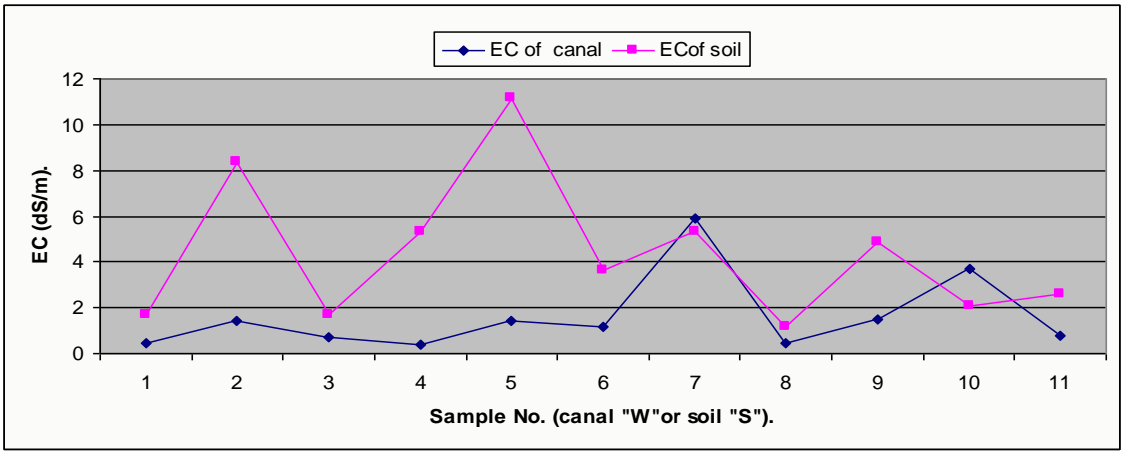

Fig. 2. EC of irrigation water and EC of soil under study samples.

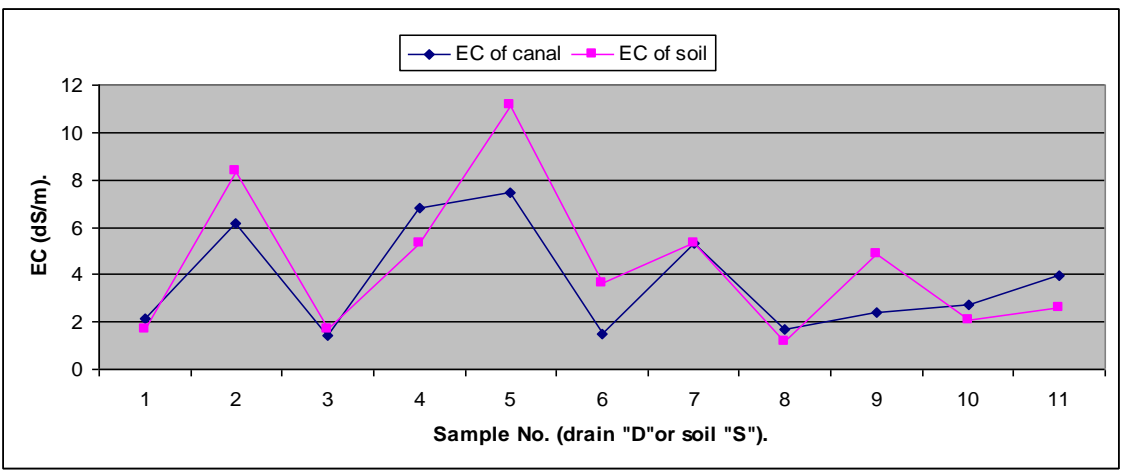

Fig.3. EC of drainage water and EC of soil under study samples.

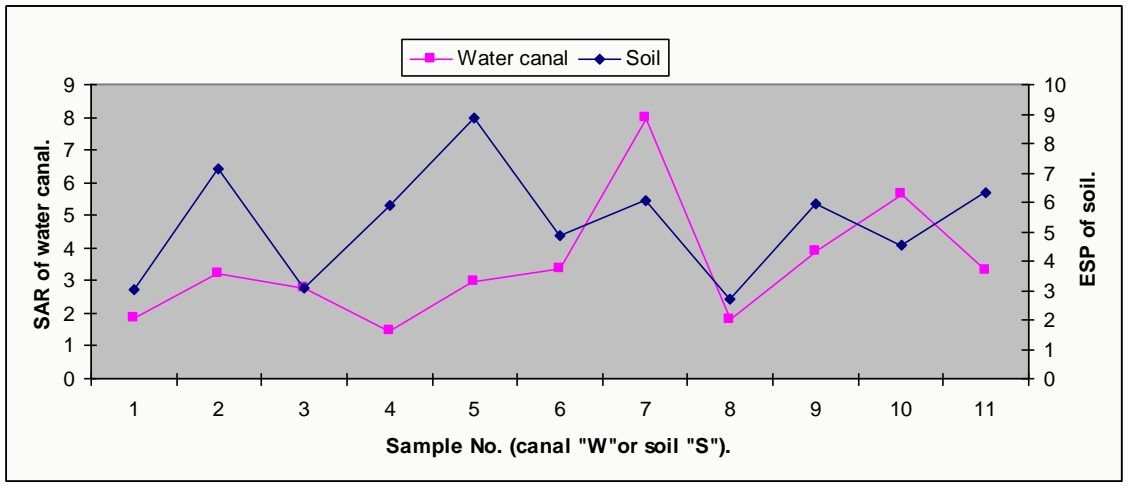

Fig.4. SAR of irrigation water and ESP of soil under study samples.

Egypt. J. Soil Sci. 54, No.2 (2014) 


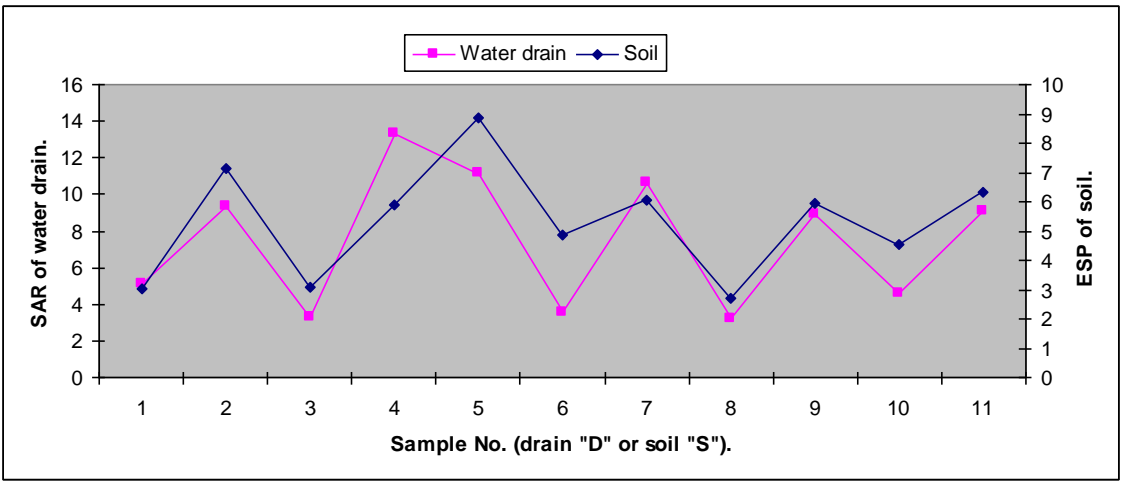

Fig.5. SAR of drainage water and ESP of soil under study samples.

\section{Conclusions}

Irrigation water in the area is classified as medium to very high hazards. EC of water ranged from $0.44 \mathrm{dS} / \mathrm{m}$ up to $5.90 \mathrm{dS} / \mathrm{m}$ and SAR ranged from 1.46 to 7.98 being a low to medium sodicity hazard. EC in drainage water ranged from 1.44 to $7.46 \mathrm{dS} / \mathrm{m}$ and SAR ranged from 3.31 to 13.34 and demonstrated a low to medium sodicity hazards due to the irrigation water. The soils are not sodic of $55 \%$ of the soils are saline non-sodic and $45 \%$ are non-saline non-sodic. However, i) to achieve a full yield potential, ii) to sustain it for long period of time and iii) to avoid the possibility of sodicity and toxicity hazardous in future, proper irrigation scheme is required in the form of crop selection, fertilizer usage and suitable management.

Acknowledgment : I would like to express my deepest thanks to Prof.Dr. Ali Ahmed Abdel-Salam, Prof. of Soil Sci., Fac., Agric., Moshtohor, Benha University., for his guidance and comments during this work. Sincere thanks are due to Prof. Dr. Hassan Hamza Abbas, Prof. of Soil Sci., Fac. Agric., Moshtohor, Benha University, for his comments during this work.

\section{References}

Abraham, T.B., Bheemalingeswara, K. and Tesfamichael, G. (2011) Suitability of groundwater quality for irrigation with reference to hand dug wells, Hantebet Catchment, Tigray, Northern Ethiopia. Department of Earth Science, College of Natural and Computational Sciences, Mekelle University, Mekelle, Ethiopia. (2): 31-47.

Amer, M.H. (1996) History of drainage in Egypt. DRI, NWRC. (In Arabic).

Bauder, T.A., Waskom, R.M., Sutherland, P.L. and Davis, J.G. (2013) "Irrigation Water Quality Criteria", Colorado State University Extension, Colorado, USA.

Egypt. J. Soil Sci. 54, No. 2 (2014) 
SUITABILITY OF IRRIGATION AND DRAINAGE WATERS IN SOUTH... 161

Burger F. and Čelková, A. (2001) Salinity and sodicity hazard in water flow processes in the soil. Institute of Hydrology, (2): 284-293. Slovak Academy of Sciences, Bratislava, Slovakia

Comprehensive Assessment of Water Management in Agriculture (2007) Water for food, water for life: A comprehensive assessment of water management in agriculture. London, UK, International Water Management Institute.

Famiglietti, J.S. (2011) Satellites measure recent rates of groundwater depletion in California's Central Valley. Geophysical Research Letters 38 (2): 112-125.

FAO. (1985) Water quality for agriculture. Irrigation and Drainage Paper No. 29. Food and Agriculture Organization of the United Nations, Rome.

Gold, M. (2009) What is sustainable agriculture? USDA, Alternative Farming Systems Information Center, USA.

Islam, M.S., Hassan, M.Q. and Shamsad, S.Z. (1999) Ground water quality and hydrochemistry of Kushtia District, Bangladesh. J. Asiat. Soc. Bangladesh Sci. 25 (1): $1-11$.

Islam, M.S., Hassan, M.Q. and Shamsad, S.Z. (2009) Assessment of irrigation water quality of Borga. Bangladesh J. Agril. Res. 34 (4): 597-608.

Kumar, R. and Singh, J. (2003) Regional water management modelling for decision support in irrigated agriculture. J. Irrig. Drain. 129: 432-439.

McCarton, L. and O'Hogain, S. (2013) "Sustainable Water Rupply in Ireland", Dublin Institute of Technology Seed Fund Report.

Pasakarnis, G. and Maliene, V. (2010) Towards sustainable rural development in Central and Eastern Europe: applying land consolidation. Land Use Policy 27 (2): 9- 545.

Rowe, D.R. and Abdel-Magid, I.M. (1995) "Handbook of Wastewater Reclamation and Reuse", p. 550, CRC Press, Inc.

Rowell, D.L. (1995) "Soil Science Methods and Applications", Library of Congress Cataloging Publication Data, New York, USA.

Siebert, S., Hoogeveen, J. and Frenken, K. (2006) Irrigation in Africa, Europe and Latin America. Update of the digital global map of irrigation areas to Version 4. Frankfurt Hydrology. Institute of Physical Geography. University of Frankfurt, Germany.

Stephens, R. (2002) Water quality and nursery crop nutrition. The Nursery Papers, Nursery and Garden Industry Australia.

Tanji, K.K. (1990) Agricultural salinity assessment and management. American Society of Civil Engineers.

USDA. (1954) Diagnosis and improvement of saline and alkali soils. USDA Handbook 60, USA. 
Zahra, W.R.A. (2007) Evaluation of soil productivity in south El-Kalubia Governorate using Remote Sensing and GIS techniques. M.Sc. Thesis, Fac. of Agric., Moshtohor, Benha Univ., Egypt.

\section{مدى ملائمة مياه الرى و الصرف في جنوب محافظة القليوبية لتحقيق التنمية الزراعية المستدامة تحت ظرفي فند الأراضى المتأثرة بالأملاح \\ هبة شوقى عبدالله راشد

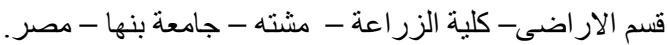

يهدف هذا البحث إلى تقييم التنمية الزر اعية المستدامة لجودة مياه الرى (مياه الترع التراه

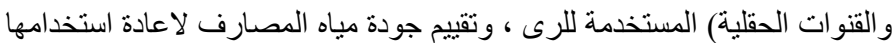

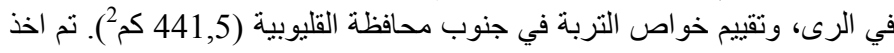

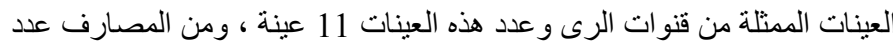

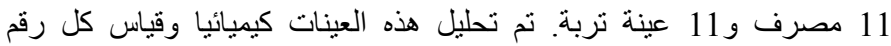

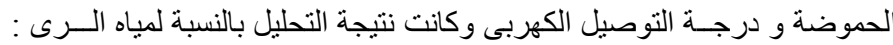

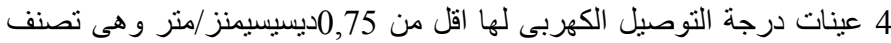

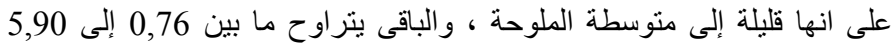
ديسيسيمنز/منز وتصنف على انها عالية إلى عالية جدا في الملوحة.

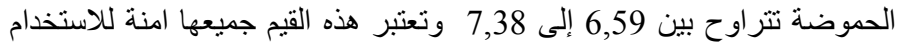

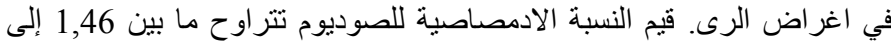

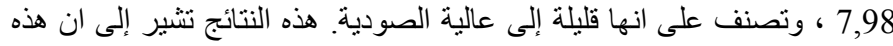

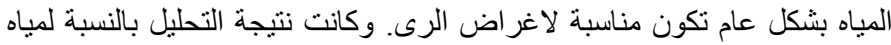

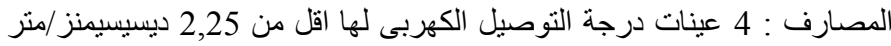

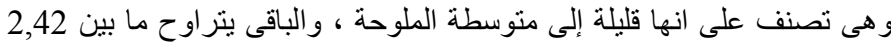

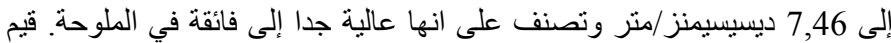

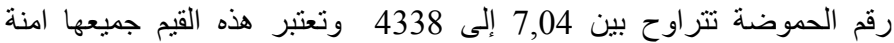

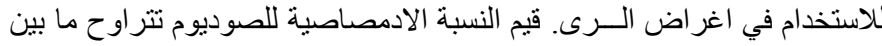

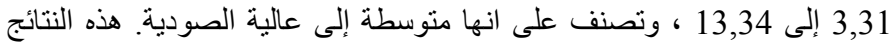

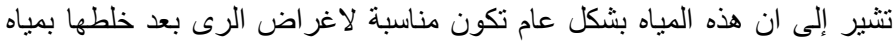

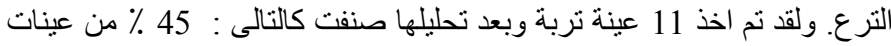

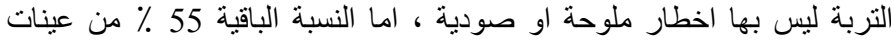

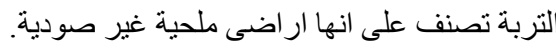

Egypt. J. Soil Sci. 54, No. 2 (2014) 